\title{
Status of the Ibera Seedeater Sporophila iberaensis
}

\author{
Tatiana Galluppi-Selich ${ }^{1,4}$, Hugo Cabral ${ }^{1,2} \&$ Rob Clay $^{3}$ \\ 1 Asociación Guyra Paraguay, Parque Ecológico Capital Verde, Av. Carlos Bóveda CC 1719, Asunción, Paraguay. \\ 2 Instituto de Investigación Biológica del Paraguay. Del Escudo 1607, Asunción, Paraguay. \\ Western Hemisphere Shorebird Reserve Network, Rodríguez de Francia 869, Asunción, Paraguay. \\ ${ }^{4}$ Corresponding author: tatiana.guyra@gmail.com
}

Received on 10 April 2018. Accepted on 03 November 2018.

\begin{abstract}
Paraguayan records of the recently described Ibera Seedeater Sporophila iberaensis are compiled and reviewed. Observations of birds identifiable to this species in Paraguay date from at least 1998, with the first photographic documentation in December 2004. The species has now been recorded at a minimum of 11 localities in the departments of Cordillera, Itapúa, Misiones, San Pedro and Presidente Hayes. The first two records of the species from Brazil (both from Mato Grosso do Sul) are also listed. Most Paraguayan records are of singing males, and breeding has been documented (a pair feeding fledglings) at one locality in Cordillera department, significantly expanding the known breeding range of the species. At least three localities appear to hold small populations (observations of multiple territorial males and/or pairs). In Paraguay, as in Argentina, the species appears to prefer wet tall grasslands bordering wetland areas. Its preference for tall grasslands makes the species particularly susceptible to habitat loss and degradation through overgrazing, frequent burning, and conversion to agriculture. These threats are all present at the principal localities for the species in the country. A reassessment of the species global conservation status taking into consideration the Paraguayan range and population suggests that it may best be treated as "Vulnerable".
\end{abstract}

KEY-WORDS: Brazil, conservation, distribution, grassland, South America, Thraupidae.

\section{INTRODUCTION}

Sporophila is a genus of about 40 species of seedeaters, almost entirely restricted to the Neotropics (Ridgely \& Tudor 2009). Classification of the genus Sporophila has been difficult at all levels, from family placement to the specific or morph status of several forms. Traditionally classified within the Emberizidae, recent morphological and molecular studies have revealed the genus to belong to the Thraupidae (Mason \& Burns 2013). Systematics have been particularly confusing for the "capuchino" group, which is primarily found in the grasslands of central and southern South America (Campagna et al. 2013). Recently, a new species of capuchino seedeater, Ibera Seedeater Sporophila iberaensis, was described from northern Argentina based on an analysis of vocalizations and plumages (Di Giacomo \& Kopuchian 2016). The male $S$. iberaensis plumage type has been observed in northern Argentina since at least late 1990s (López-Lanús et al. 2013), but its taxonomic status had been unclear due to its similarity to the pre-definitive plumages of other capuchino species.

Currently the species is listed as "Endangered" on the IUCN (International Union for Conservation of Nature) Red List. This categorization was recommended by LópezLanús et al. (2013) due to the very small population size of the species, that is thought to be declining as a result of habitat loss and degradation and potentially it being captured for trade (BirdLife International 2017). A reassessment of the currently species categorization is needed, taking into consideration all the information about its distribution in Paraguay and Brazil.

To date, 15 species of Sporophila have been recorded in Paraguay (SACC 2016). Here we present an overview of the known records of $S$. iberaensis in the country (five of which were mentioned by Di Giacomo \& Kopuchian 2016) and discuss the status of the species. We also present the first two records of the species in Brazil (one of which was mentioned by Di Giacomo \& Kopuchian 2016).

\section{METHODS}

Records of $S$. iberaensis were compiled from published literature and technical reports, our field observations and those of other observers, eBird (www.ebird.org) and the Guyra Paraguay biodiversity database. The previously unpublished record from Brazil was discovered by reviewing photos in WikiAves (http://www.wikiaves. com.br/). This species differs from other species of Sporophila since males present a leaden gray crown and forehead that contrast with the nape, coverts, ear coverts, and blackish brown chin and throat. The back and rump are olive brown; breast, belly and under tail coverts are 
pallid yellow to buffish; white base rectrices same color as the dorsal wing-bar, which is slightly larger from the other seedeaters. Females of this species are alike other species of seedeaters (López-Lanús 2015, Di Giacomo \& Kopuchian 2016). Previously, S. iberaensis has been confused with individuals of Sporophila ruficollis (Darkthroated Seedeater) which has an odd pre-definitive plumage. After revision of both species, they were separated due to behavior (vocalizations and breeding area) and morphological attributes (López-Lanús 2015, Di Giacomo \& Kopuchian 2016). The location of each record was digitized using ArcGIS software, and habitat information was gathered when available.

All confirmed records of the species were used to generate the Minimum Convex Polygon for the species' distribution. To select an optimal grid size for assessing Area of Occupancy (hereafter AOO) and Extent of Occurrence (hereafter EOO), the distances between all locations were calculated, and the average distance in $\mathrm{km}$ used to determine grid size $(15 \times 15 \mathrm{~km})$. For the extent of occurrence all grids within a $10 \mathrm{~km}$ radius from each point were selected, in recognition of the likelihood of the species occurring in similar habitats in areas adjacent to known localities.

Nomenclature follows the South American Classification Committee - SACC (http://www. museum.lsu.edu/ $/$ Remsen/SACCBaseline.htm), with the exception of $S$. iberaensis (as the taxon has yet to be recognized by SACC). For the latter, Di Giacomo \& Kopuchian (2016) and IUCN (2017) are followed.

\section{RESULTS}

Records of S. iberaensis in Paraguay date from at least October 1998, when a male was observed by R.C. close to a locality where the species is now regularly recorded. The first known documentation of the species in the country are photos of a male at $\mathrm{km} \mathrm{97,} \mathrm{Ruta} 3$ by F. Fragano (in litt.) on 05 December 2004, the photo is available on this link, (http://www.faunaparaguay.com/sporophila_ iberaensis.html). Increasing awareness of this distinctive plumage-type led to more reports from $c .2008$ onwards, and the species has now been reported from 11 localities in the departments of Cordillera, Misiones, Itapúa, San Pedro and Presidente Hayes (Table 1, Fig. 1).

Many records of the species are from the Important Bird Area (IBA) PY025 Arroyos y Esteros, which is dominated by humid grasslands with species of the Poaceae family and the presence of annual and perennial herbs (Cartes \& Clay 2009, TNC 2005). This area is very similar to others where the species has been recorded such as the IBA PY034 Campo Llano, which is characterized by the presence of flooded grasslands with marshes and gallery forest (Fig. 2; Josse et al. 2003, Cartes \& Clay 2009).

To date, all but one record of the species have been in eastern Paraguay. The one record from western Paraguay (the Humid Chaco) is from an area of open flooded palm savanna with the predominant grass species being Poaceae family (TNC 2005, Cartes \& Clay 2009).

Nearly all Paraguayan records of $S$. iberaensis are from the austral spring (September to December) and summer (December to January), with just one record from the austral winter (June 2004). Apart from this one exception, regular visits to appropriate habitat (including a confirmed breeding site) outside of September to January have not recorded the species.

Apparent pairs and singing males have been recorded at three localities during October to January, with breeding confirmed at one (a pair feeding young in two consecutive years at Ruta Juan de Mena, O. Bordón, in litt. 2017), representing a northward extension of the breeding range by about $300 \mathrm{~km}$. Multiple males have

Table 1. Locations and first observations of S. iberaensis in Paraguay.

\begin{tabular}{lll}
\hline Date & Locality & Observer \\
\hline 31 October 1998 & Nu Guazú, General Artigas, Itapúa department. & R.C. \\
07 January 1999 & Río Tacuary wetlands, Itapúa department. & R.C. \\
June 2004 & Campo Llano, Misiones department. & A.J. Lesterhuis \\
05 December 2004 & km 97, Arroyos y Esteros, Cordillera department. & F. Fragano \\
October 2008 & Ruta Juan de Mena, Cordillera department. & P. Smith \\
October 2008 & Bajo Chaco, Presidente Hayes department. & C. Morris \\
06 October 2011 & San Cosme y San Damián, Itapúa department. & C.D. Timm \\
08 December 2014 & Yabebyry, Misiones department. & A.J. Lesterhuis \\
January 2016 & Santiago, Misiones department. & T.G., R. Ruiz, S. Rojas \\
November 2017 & Colonia Volendam, San Pedro department. & M. Fast, M. Ens \\
13 December 2017 & Estero San Mauricio, Itapúa department. & T.G., V. Rojas \\
\hline
\end{tabular}


been recorded at all three localities, with a high count of nine males at Ruta Juan de Mena in December 2016 and January 2017 (Fig. 2).

Di Giacomo \& Kopuchian (2016) list one record of $S$. iberaensis from Brazil, a male photographed and videoed by J. del Hoyo at Pousana Aguapé, Mato Grosso do Sul state on 09 January 2005 (http://ibc.lynxeds.com/ species/dark-throated-seedeater-sporophila-ruficollis). A second record, clearly identifiable as $S$. iberaensis was photographed at Miranda, Mato Grosso do Sul state by N. Cabral on 26 August 2015 (http://www.wikiaves. com.br/1933758\&p=27\&t=s\&s=11672).

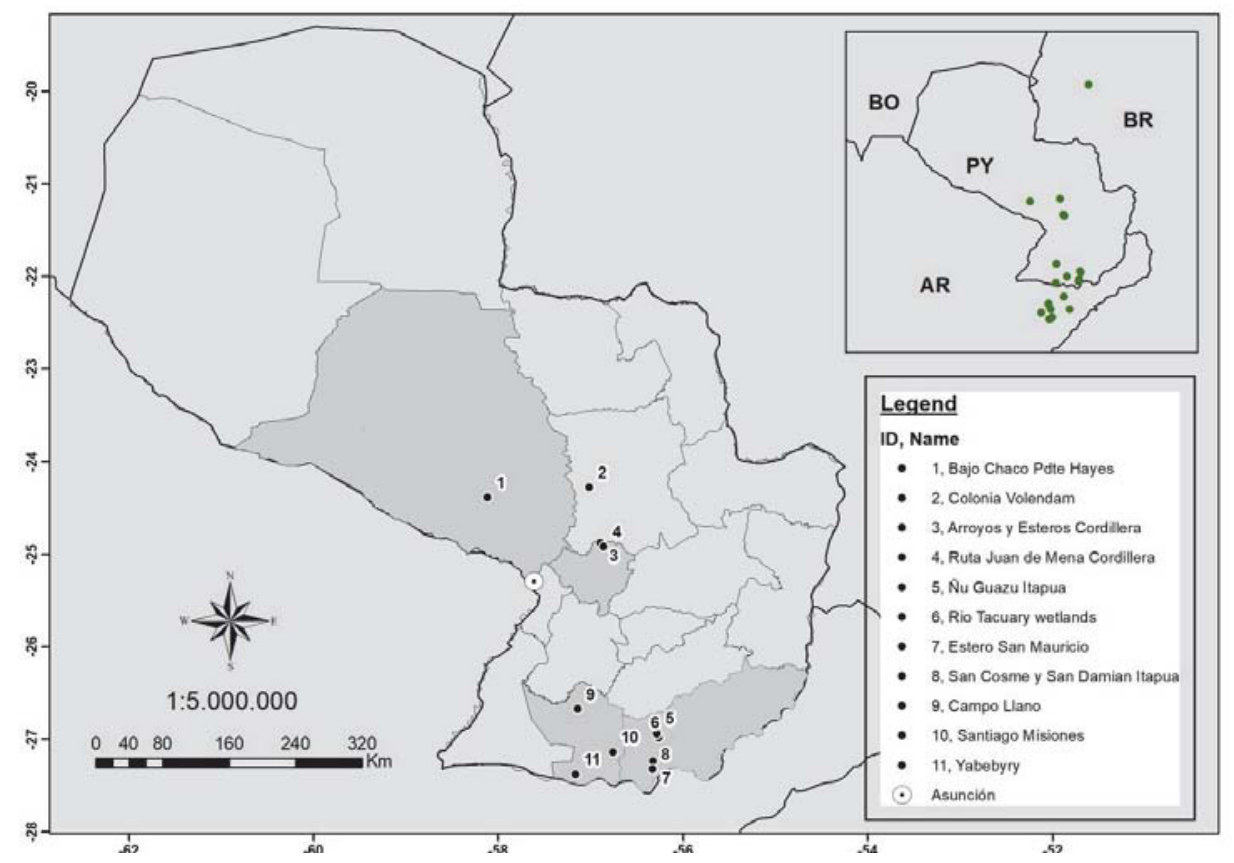

Figure 1. Records of Sporophila iberaensis in South America. Gray triangles: new localities with records of S. iberaensis including records from literature and other sources (Denton 2010, Smith \& del Castillo 2012, López-Lanús 2015, Smith \& Clay 2015).

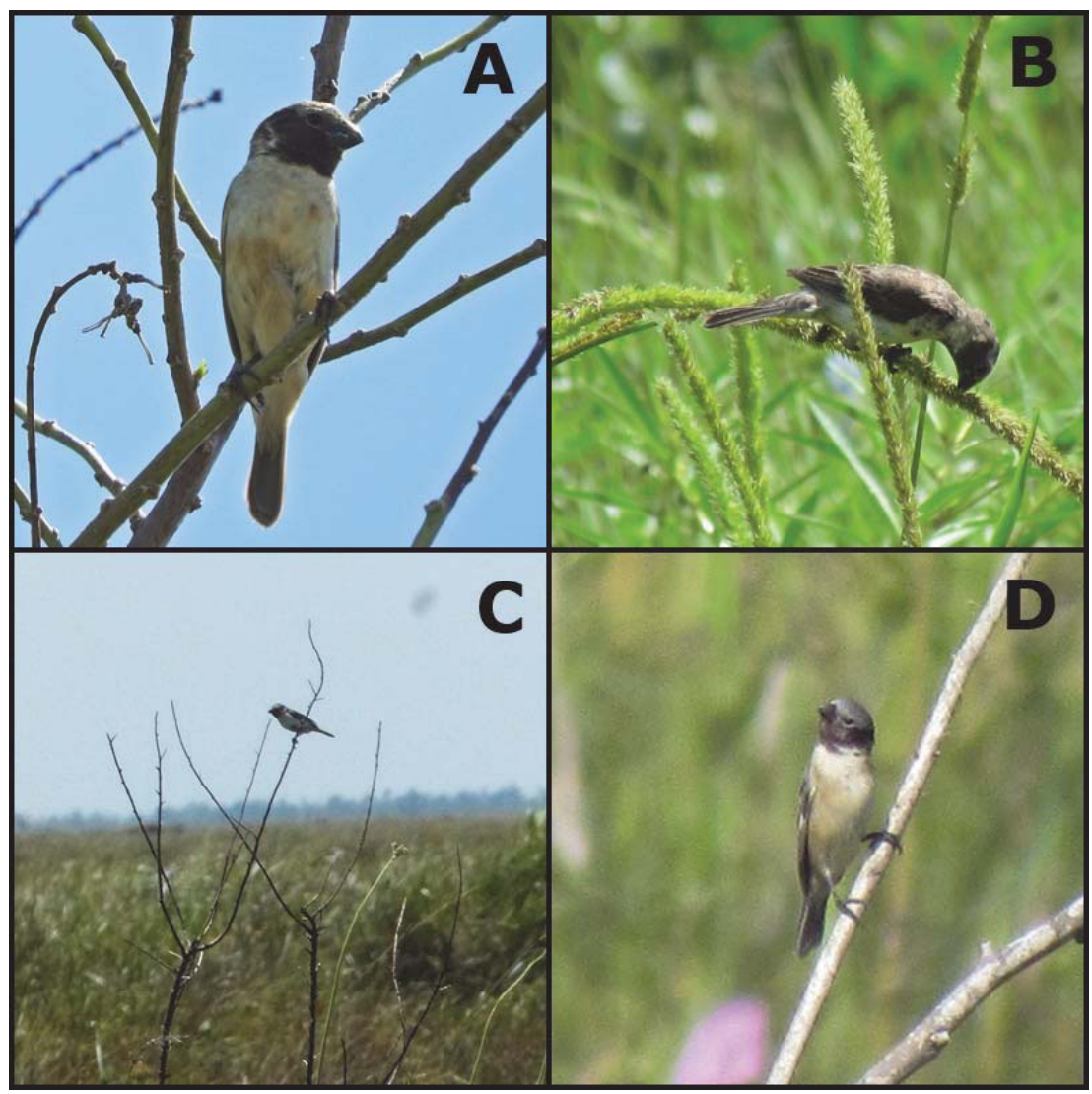

Figure 2. Sporophila iberaensis in Santiago, Misiones (A \& B); in Campo Llano, Misiones (C); in Juan de Mena, Cordillera (D). Photo authors: R. Ruíz (A), T. Galluppi (B \& D), H. Cabral (C). 


\section{Conservation status}

Ibera Seedeater is currently listed as "Endangered" at a global level under the criterion C2a(ii) of the IUCN Red List (IUCN 2017). This assessment was based on the species known distribution in Argentina, where it appears to be restricted to the Ibera Marshes and adjacent grasslands in Corrientes province (IUCN 2017). Given this restricted distribution, it was assumed to be one subpopulation, and to number less than 1000 mature individuals (Di Giacomo \& Kopuchian 2016, IUCN 2017).

With documentation of the species range to include southeastern and central Paraguay, its conservation status warrants reassessment. Taking into consideration the species apparent breeding range in Paraguay, S. iberaensis has an EOO of 62,046 $\mathrm{km}^{2}$ in Argentina and Paraguay, and an AOO of $12,365 \mathrm{~km}^{2}$ (Fig. 3). The two Brazilian records have been excluded from these calculations given that they may be part of the non-breeding range of the species.

While judging the limits of subpopulations of a migratory species can be particularly difficult, it seems plausible that there are at least two subpopulations within Paraguay, one located in the extreme southeast (Itapúa and Misiones departments, and likely connected to the subpopulation in Argentina) and one in the center (Cordillera and San Pedro, and potentially Presidente Hayes departments). However, the apparent gap in distribution could also be the result of undersampling or local extinctions.

Although the Paraguayan records significantly expand the range of the species, the numbers recorded at any one site are low, and it seems very likely that the total number of mature individuals in the overall population is less than 10,000 (and possibly not more than 1000). Combined with an estimated and projected continuing decline in mature individuals due to habitat loss of at least $10 \%$ in 10 years, this triggers Red List criterion C1 in the category "Vulnerable". If further research reveals that there are discrete subpopulations, then a higher level of threat may be warranted under C2a.

The species population is considered to be declining primarily due to habitat loss (IUCN 2017). Its preference for tall grasslands makes it particularly susceptible to habitat loss and degradation through overgrazing, frequent burning, and conversion to agriculture. These threats are all present at the main localities for the species in Paraguay. Worryingly, the species is not currently known from any formally protected areas in Paraguay.

\section{DISCUSSION}

Southern and central Paraguay is clearly an important part of the range of $S$. iberaensis, with records of multiple individuals and apparent pairs in appropriate habitat and

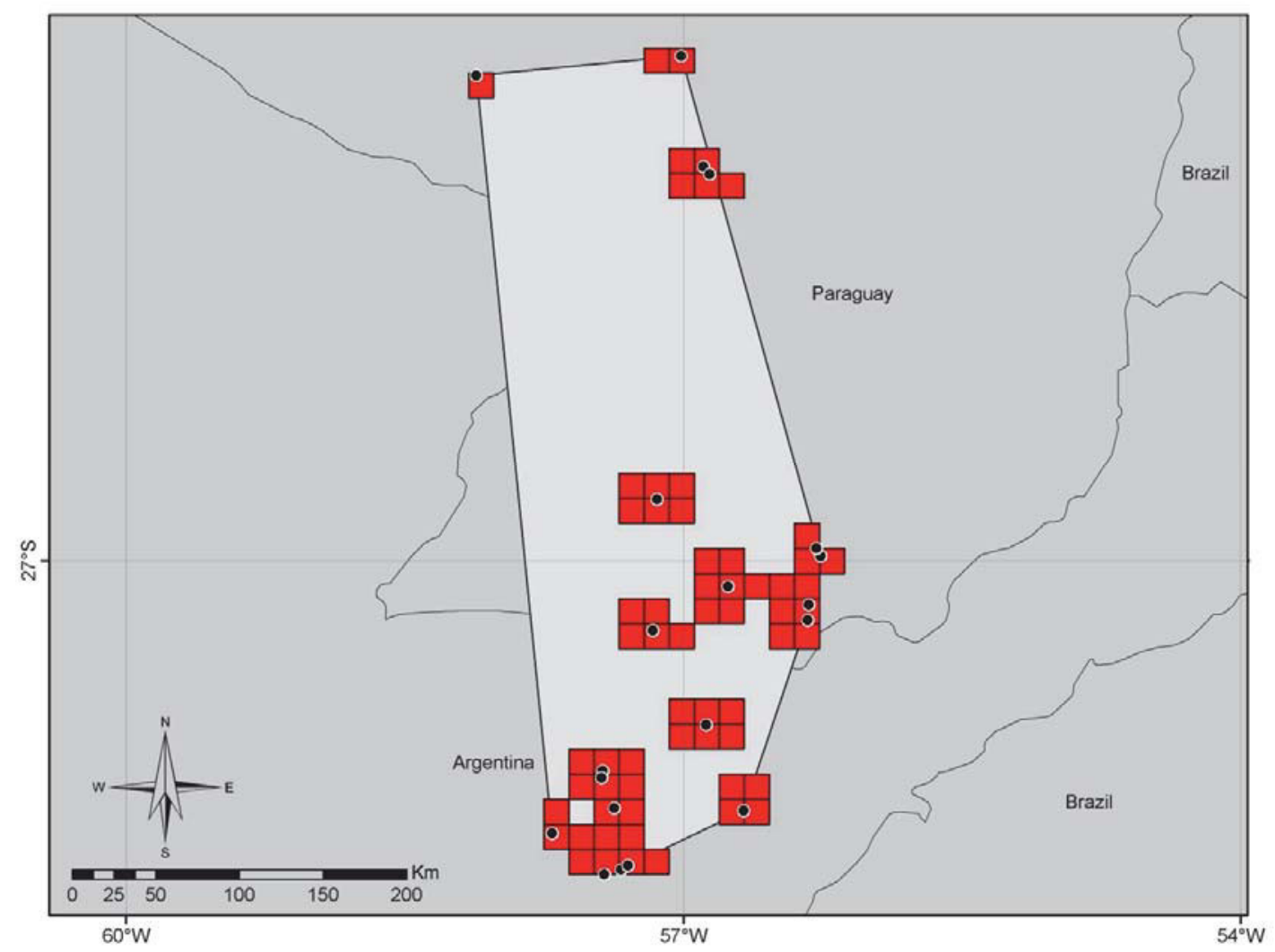

Figure 3. Area of occupancy (AOO) of Sporophila iberaensis. The species has been recorded from or is considered likely to occur in 54 grid squares of $15 \times 15 \mathrm{~km}$. 
breeding confirmed in one area in Cordillera department. Records are primarily from the austral summer, and it seems likely that as with other capuchino seedeaters, $S$. iberaensis winters to the north, in Brazil. The two records from Mato Grosso do Sul state support this, though the first is an atypical date for a wintering bird (or migrant), and perhaps represents a bird over-summering on the wintering grounds, though it also raises the possibility that the breeding range may extend into southwestern Brazil.

Paraguayan localities for the species are primarily from the Mesopotamian Grasslands and Humid Chaco ecoregions (Dinerstein et al. 1995, del Castillo \& Clay 2004), where the species has a preference for tall wet grasslands, and may be an indicator of the degree of ecological integrity of such grasslands (as proposed by López-Lanús et al. 2013). The one confirmed breeding location and the record from San Pedro department are in grasslands associated with the Humid Chaco ecoregion (Dinerstein et al. 1995, del Castillo \& Clay 2004), but in a transitional zone toward more Cerrado-like grasslands.

Ibera Seedeater can often be found in proximity to other threatened grassland birds such as Strangetailed Tyrant Alectrurus risora and Chestnut Seedeater Sporophila cinnamomea. All three species and the habitats they depend upon are all increasingly threatened in Paraguay from conversion to agriculture, overgrazing, frequent burning, and the drying of wetland habitats.

A reassessment of the global conservation status of the species taking into account its Paraguayan range and population suggests that the species should perhaps best be considered "Vulnerable" under criterion C1. The Paraguayan National Red List assessment is currently being updated, and the species has been proposed as "Vulnerable" under criteria C1. Given the significant overlap in range and threats as other capuchino seedeaters, similar conservation measures should be implemented for S. iberaensis, including listing on Appendix I of the Convention of Migratory Species, creation of a protected area within its Paraguayan range, and working with ranchers to set-aside areas of appropriate habitat during the breeding season. Furthermore, observers are encouraged to document new records and localities for the species. These records could include the department of Paraguari, in order to sustain the idea that there are two subpopulations of the species; and in particular to search for it in southwestern and central Brazil during the austral winter.

\section{ACKNOWLEDGEMENTS}

We thank Paul Smith, Oscar Bordón, Oscar Rodríguez, Rodolfo Ruíz, Arne Lesterhuis, Marko Fast, Nelson
Cabral and Roberto Derna for providing information about their records; Viviana Rojas and Carlos Giménez for comments that improved the manuscript. H.C.B. and T.G.S. would like to thank the National Science and Technology Council (CONACYT) for funding support for the 14-INV-063 Project. Also H.C.B. would like to thank CONACYT for funding support through the PRONII program.

\section{REFERENCES}

Campagna L., Silveira L.F., Tubaro P.L. \& Lougheed S.C. 2013. Identifying the sister species to the rapid capuchino seedeater radiation (Passeriformes: Sporophila). Auk 130: 645-655.

Cartes J.L. \& Clay R.P. 2009. Áreas importantes para la conservación de las aves en Paraguay. Asunción: Guyra Paraguay/BirdLife International.

del Castillo H. \& Clay R. 2004. Annotated checklist of the birds of Paraguay. Asunción: Guyra Paraguay.

Denton M. 2010. BirdQuest Paraguay Tour Report. http://www. birdquest-tours.com/pdfs/report/PARAGUAY\%20REP\%2010. pdf (access on 14 December 2018).

Di Giacomo A.S. \& Kopuchian C. 2016. Una nueva especie de capuchino (Sporophila: Thraupidae) de los Estero del Iberá, Corrientes, Argentina. Nuestras Aves 61: 3-5.

Dinerstein E., Olson D.M., Graham D.J., Webster A.L., Primm S.A., Bookbinder M.P. \& Ledec G. 1995. Una evaluación del estado de conservación de las ecorregiones terrestres de América Latina y el Caribe. Washington: Banco Mundial.

IUCN [International Union for Conservation of Nature]. 2017. The IUCN Red List of threatened species v. 2017-3. http://www. iucnredlist.org/details/103818544/0 (access on 09 September 2017).

Josse C., Navarro G., Comer P., Evans R., Faber-Langendoen D., Fellows M., Kittel G., Menard S., Pyne M., Reid M., Schulz K., Snow K. \& Teague J. 2003. Ecological systems of Latin America and the Caribbean: a working classification of terrestrial systems. Arlington: NatureServe.

López-Lanús B. 2015. Una nueva especie de capuchino (Emberizidae: Sporophila) de los pastizales anegados del Iberá, Corrientes, Argentina, p. 473-489. In: López-Lanús B. (ed). Guía Audiornis de las aves de Argentina, fotos y sonidos, identificación por caracteristicas contrapuestas y marcas sobre imágenes. Buenos Aires: Audiornis Producciones.

López-Lanús B.M., Di Giacomo A.S., Azpiroz P., Haynes P., Galimberti A., Keyel A., Ocampo A., Güller R., Moller-Jensen R., Mattalía M., Cardozo H., Giarduz C., Papini G. \& Di Giacomo A.G. 2013. Inventario focal de fauna de las estancias La Higuera, María Concepción, La Sirena y Virocay en el sitio piloto Aguapey: Corrientes, Argentina, p. 135-170. In: Marino G.D., Miñarro F., Zaccagnini M.E. \& López-Lanús B. (eds.). Pastizales y sabanas del cono sur de Sudamérica: iniciativas para su conservación en la Argentina. Buenos Aires: Aves Argentinas/AOP y Fundación Vida Silvestre Argentina.

Mason N. \& Burns K.J. 2013. Molecular phylogenetics of the Neotropical seedeaters and seed-finches (Sporophila, Oryzoborus, Dolospingus). Ornitología Neotropical 24: 139-155.

Ridgely R.S. \& Tudor G. 2009. The birds of South America: Passerines. London: Cristopher Helm.

SACC [South American Classification Comitee]. 2016. A classification of the bird species of South America. http://www.museum.lsu. edu/-Remsen/SACCBaseline.htm (access on 27 December 2016). 
Smith P. \& del Castillo H. 2012. BirdQuest Paraguay tour report. http://www.birdquest-tours.com/pdfs/report/PARAGUAY\%20 REP\%2012-ebook.pdf (access on 14 December 2018).

Smith P., Clay R. \& Morris P. 2015. BirdQuest tour report: Paraguay Neotropical Bird Club Fundraiser. http://www.birdquest-tours. $\mathrm{com} / \mathrm{pdf} /$ report/PARAGUAY\%20-NBC-\%20REP\%20 15-ebook.pdf (access on 14 December 2018).

TNC [The Nature Conservancy]. 2005. Evaluación ecorregional del Gran Chaco americano. Buenos Aires: Fundación Vida Silvestre Argentina.

Associate Editor: Luis F. Silveira. 